\title{
Social Capital. Viewing Nordic Paths of Management
}

\author{
Noralv Veggeland \\ Professor of Public Policy \\ Dept. of Economics and Organization Science, \\ Inland Norway University of Applied Sciences, Lillehammer, Norway
}

doi: 10.19044/esj.2017.v13n10p18 URL:http://dx.doi.org/10.19044/esj.2017.v13n10p18

\begin{abstract}
How do Nordic states conduct policies in order to bring people closer to the socio-economic realm, in the sense that they, being social capital, tend to be integrated as active and participatory citizens? How do the interventionist and expensive Nordic welfare states survive in the global age, with demanding and ever changing claims to international competitiveness?

This paper addresses these questions. Social capital and partnership building are introduced as terms and policy concepts in order to find answers in the framework of intended or unintended strategic endeavours. As a critical approach claims a contextual conceptualisation, we shall here view different European social models and administrative traditions in relation to comparative basic contexts in order to arrive at analytical answers. Leaning especially on the Anglo-Saxon model, the traditional Scandinavian universal welfare state model of the post-war Keynesian order has gradually been transformed into the contemporary Nordic model (Veggeland 2007). Contextual regulatory innovations and path-dependent processes have generated the survival of universal welfare state arrangements and collective action but with the mixed use of Market-Type Mechanisms (MTM) in the public sector of Anglo-Saxon origin. In summary, this blending of policies has resulted in the advantageous social capital of what is called flexicurity, social security combined with a flexible participatory labour market. We shall discuss both flexicurity policy and participatory subsidiarity defined downwards as contribution to an explanation of why the expensive welfare states of the Nordic type have not only so far been doing well but have also sustained both democratic and output-side legitimacy.
\end{abstract}

Keywords: Administrative traditions, Nordic model, structural threats, subsidiarity 


\section{Social capital and innovation}

The European Union (EU) is in a deep crisis of identity as many times earlier in its history. Again Europe is looking for ideas and concepts of social capital that might constitute and give the integrated global regions an impetus to more sustainable economic activity, employment, and welfare, through collective action and renewed endogenous development, both inside countries and across national borders (Cini (ed.) 2004, Hayward and Menon (eds.) 2003). Partnership-building that connects private and public actors as well as public actors to other public actors has the intention of strengthening existing social capital (Putnam 1993) and raising new social (and human) capital as strategic concepts for promoting economic renewal and sustainable welfare (Szreter and Woolcock 2004). The concepts draw upon the belief that pooling actors in micro or macro networks (clusters according to Porter 1998) and organised 'institutional thickness' (Amin and Thrift 1995a) in the form of collective action are basic policy strategies when the target of the polity is to achieve and increase competitive development capacity. The strategy goes for organising existing or new public and private actors for collective actions through contracts and partnership formations, both nationally and locally, as we know recommended by European development programmes. Additionally, partnership institutions fit into the mode of arm's-length steering, which characterises the regulatory state (Keating 1998). The beneficial outcome is the advantages that come with the building of extensive social capital. We may, however, view social capital as a diversified notion (Veggeland ed. 2016).

The concept of social capital came about in the James C. Coleman's (Sørensen and Spilerman 1993) ${ }^{1}$ and Robert D. Putman's (Putman (ed.) 2002) version in the US in the 1980s. It was part of a major political change that took place in those years in the Anglo-Saxon US and the UK and had wide-ranging consequences. The neo-liberal economic discourse and NPM organisational changes entered the global scene. Social capital became an imperative economic notion. A critical expression became resonant: social capital, social but still capital (Navarro 2002, 2004). A past president of the American Political Science Association, Theodore Lowi, indicated that 'economic language is the dominant language in social science discourse today ...... we are witnessing the de-politicization of politics' (1992:86). In other words, it implies that social capital building has become a narrow concept based only on economic values. Contrary to this reductive notion, there also exists a wider concept of social capital that accounts for additional social and sustainable ethical values.

${ }^{1}$ See Social theory and social policy: essays in honour of James S. Coleman / edited by Aage B. Sørensen and Seymour Spilerman. Westport, Connecticut; London Praeger. 
The term 'social capital' reflects not only the understanding that government needs capital but that individuals need capital in order to compete or survive better in the competitive and microeconomic world as well (Veggeland ed. 2016). As capital, investment in building social capital creates, therefore, expectations first and foremost of economic revenues derived from the social realm and expectations about business growth; if not these do not happen, the investment is deemed a failure. We may express this notion in the following way. Building social capital within this framework of economics tends to become an art of social and human engineering (Beetham et al. 2002, Moran 2003). The target of this art is the creation of competitive micro-partnership formations and joined-up initiatives, but such targets are often based on short-term market thinking and changes, and thereof the frequent shifting of partner alliances.

\section{Comparison of social models}

Michael Moran's thesis (2003) is that social capital in the sense of engineered micro-partnerships and institutional changes has been a 'fiasco' with the consequence of generating more innovation in an ever ascending, or more accurately, descending, spiral (Veggeland 2013). Moran argues that in the Anglo-Saxon UK, the last 30 years have been an era of 'hyperinnovation', displaying 'the frenetic selection of new institutional modes like partnerships and arm's length bodies, and their equally frenetic replacement by alternatives' (2003:26). Other scholars have supported this thesis (Scharpf 1999, Veggeland 2004, ed. 2016, Higdem 2007). It might have caused the Brexit from the EU.

The implication of Moran's thesis is that partnership-building of this kind encourages collaborative governance and collective action at the microlevel because of 'spill-over' effects. It becomes a strategy for taming fragmentation, inefficiency, and increasing transactional costs. Further, its unexpected 'spill-over' effects will manifest as unpredictable actions and sudden dilutions of partnerships, which demand replacements. Individualised interest conflicts and social inequality among the partners devastate partnerships and cause the 'frenetic replacement by alternatives'. Increasing transactional costs becomes another threat because of this 'ascending, or descending, innovation spiral'. We should, however, understand this properly. Of course, the partnership concept as collective action and social capital of the engineered, economically valued variety also, in general, encourages good governance. Theodore Lowi and Vincent Navarro have, however, identified the problem: the narrow and economically valued concept of social capital does not only lead to the de-politicisation of politics but may contextually, depending on social models, be a barrier for building 
wider-valued social capital at the societal macro-level. With this in mind, let us study some lessons from Scandinavia.

With regard to the prospect of good governance within the framework of national macro-partnership for collective action, for example, Simon Szreter and Michael Woolcock (2004) have concluded that the Swedish welfare state provides social capital of the wider-valued type to its citizens in a better way and more innovatively than do other social models. How have these scholars supported such a statement? Let us test their suggestion in a wider Nordic framework.

Taking Szreter and Woolcock's statement seriously, we must say that they made such an assertion based on a consideration of what is good or deficient social capital. In other words, they must have drawn the conclusion on the grounds of preferable Swedish welfare norms, social ethics, and valued results, which the actual social model fulfils. They conclude indirectly that social science should be able to say whether or not social capital building has led to 'successes' along a scale of goal achievement. It means we need criteria against which to assess and measure success or failure. Neither Szreter and Woolcock nor Moran with his 'fiasco' statement indicates such criteria. Actually, reviewing the issue of 'good-bad' governance critically from a normative point of view is all too rarely done (Black 2005).

What we do know though is that social models and administrative traditions, which naturally have come into being in a socio-economic framework of values and experiences, do influence the quality and practical outcome of institutional change (Veggeland 2013, Pedersen 2008, March and Olsen 1989), and consequently also the formation of partnership and the provision of social capital. Let us review the Swedish case a little further. Szreter and Woolcock's observations warrant a serious consideration of the Swedish welfare-state model as a major point of reference in order to determine macro social capital in a wider normative framework than the instrumental approach to the concept often does.

In what follows, we shall take that approach, but we shall view the Swedish model within the framework of the major Scandinavian-Nordic model, in which the former model represents the core (Veggeland 2007). Szreter and Woolcock refer to 'other societies' in their statement but do not point out which ones. Here we shall address this oversight by making a comparison of macro social capital formation and policy belonging to the Nordic model and its constituent countries, which are thought influenced normatively with social-capital policy from the Anglo-Saxon model and the Continental model. Regarding the former model, the focus will be on the social-democratic tradition responsible for the promotion of social capital 
based on universal welfare and social security, an active labour-market policy, and an interventionist and comparatively expensive state.

Contemporary focus on the building of social capital through various partnership formations is a key part of the debate on both 'reinventing government' (Osborne and Gaebler 1993) and 'rediscovering institutions' (March and Olsen 1989). As such, the focus reflects the pandemic search for ideas of institutional change and innovation in the global age (Cassese 2003). However, the search for and the adoption of ideas do not happen randomly but are linked to contextual 'interpretation' of values and substance (Røvik 2007). Accordingly, this implies that social models and administrative traditions affect the interpretation of concepts of social capital and their attendant policy, which results in diversified implementation (Veggeland 2007).

Table1. The deviant Nordic model: Public outlays, taxes, and employment in the context of European social models.

Indicators:

Government outlays as

$\%$ of nominal GDP

Taxes as \% of GDP (2009)

Unemployment rates (2010)

*Represented by Ireland and UK, Germany.
Social models:

Anglo-Saxon* Nordic** Continental***

$43-45 \% \quad 48^{2}-58 \% \quad 47-54 \%$

$31-37 \% \quad 45-51 \% \quad 42-46 \%$

4.4-4.7 $5.4-8.8^{3} \quad 9.5-9.7$

** The five Nordic countries, *** Represented by France and (Denmark, Finland, Iceland, $\quad$ OECD data 2005

Norway, Sweden)

With references to the issue of reinventing government and the debate on public innovation and its framework, the term and concept of social capital is related to this debate and reviewed in its framework.

In a comparative perspective, there are a number of ways to demonstrate the deviant position of the Nordic-model countries. One way is to look at the size of the public sector measured as general, total governmental outlays as a percentage of the nominal GDP and as total taxes as a percentage of the GDP (Table 1). This indicates the degree to which governments and countries' citizens are willing to spend money on collective rather than individual goods in society. Welfare and social security issues are part of the collective approach. It is a historical fact that this willingness is lowest in the Anglo-Saxon tradition and highest in the Nordic tradition but with the Continental tradition close up to in substance. This is not so strange when we account for the historical roots and framework of the Scandinavian welfare-state model having its origins in the Prussian collective thinking of

${ }^{2}$ Finland's 48 per cent makes an acceptance because of lasting repercussions after the collapse of the Soviet Union.

${ }^{3}$ Finland 8.8 per cent, see previous footnote explanation. 
the late nineteenth century and the performance of the Weberian neutral bureaucracy (Kuhnle 2000). The unemployment rate is on a low level (even lower in 2007 3-5 per cent) but slightly higher than what the Anglo-Saxon model provides. The question is what legitimates a high tax level among people, and what role does social capital play regarding the social-model figures presented in Tab.1?

\section{Innovative Action and structural change}

Social constructions, like engineered partnership as social capital, are precarious, tending to erode and dissolve over time, especially when shortterm economic revenues are expected (Veggeland 2003). These aspects concern the survival of social models and administrative traditions. In contrast, building long-term social capital presupposes basically the existence of values found in local networks, identity, mutual consent, social equality, and community life, besides public and private funding access. Some social models may be good fits for these values and comparatively better than others (Iversen 2005, Knill 2001). Accordingly, these social models tend to benefit from administrative traditions that contribute to social equality, universal welfare, and social security (Veggeland 2007), in addition to the stable networking of local and regional communities. Robert D. Putnam (1993) has stressed the latter in his study of the developmental success in Northern Italian communities in the 1980s. Tight collective networking communities provided long-term, 'great' social capital (Veggeland 2013).

In our knowledge-based economy, we are constantly looking for networking partnership and collaborative governance principles, i.e., models of collective action. This search aims to find outstanding and innovative policy ideas that organise those socio-economic bodies that make collaborative developments work. Network bodies should involve the public sector and private partners in innovative clusters across all sectors and areas of the polity, among others, Michael Porter says (2000).

As such, we find public innovation measured in the context of a geographical area (state, regions of different scale), or a particular policy domain (welfare, labour market, environment), or some other unit of analysis (an organisation, individual), or some combination of the two (social regulation or labour marked in Scandinavia) (see, for example, Pedersen 2008). Actually, public innovation is about intervention and co-ordination of joint activities aimed at social capital through network and partnership formations by territory, by function or even by transcending national and transnational policies. Public innovation defines in the knowledge-based society the building and performance of new accountable and beneficial collective skills and knowledge capabilities, through social as well as human 
capital, and through fixed strategic processes in order to achieve and realise this capability (Warden, F. van 1995).

Accordingly, public innovation in networks and matters of strategic policy imply, on the one hand, transcending fiscal and regulatory interventions and the territorial and functional creation of new organisations like partnerships, either as public-private or public-public partnerships. On the other hand, such innovations also dispose change in norms, rules, standards, and operating procedures; these changes influence the conceptualisation of the reform processes. Basically, path-dependence created by social models and an administrative tradition that makes the changes contextually impacted and deep-rooted circumscribes such interventions (Veggeland 2007, Pierson 2004). Simply put, public innovation means the use of new solutions to address old problems, or old solutions to address 'new' problems of development. Generally, we may see institutional innovation as the pursuit of the modern, all-embracing project of change with regard to rationalisation, systematisation, and ordering, but this change does not take place a political and ideological vacuum (Meyer 2000).

Yet, if all innovations are change, are all changes innovations? The latter, converse statement cannot be an appropriate and reasonable conclusion. We should approach network innovation contextually and view it as the application of new solutions to old problems, or new solutions to newly 'constructed' problems. This idea has inspired studies that have attempted to determine the criteria for differentiating superficial and shortterm policy changes from deep-rooted and long-term innovations. A typology of policy change is germane here. Three forms of changes are identified:

- The first-order of change is instrumental, defining changes to the levels and settings of basic instruments like technology and budgetary restrain. Hall does not regard instrumental changes as innovative.

- $\quad$ Second-order changes are those that refer to modifications in the use and administration of the instruments in relation to current organisational processes. But the art of engineering changes neither the overall goals of policy, norms, and values nor the understanding on which the changes are based. Because these second-based changes occur within existing social models and traditional frameworks of values and norms without disturbing them, they may serve to reinforce the path-dependence of the models. Paradoxically, they may counteract reformatory change and thereof deeprooted and long-term innovations. The instrumental concept of social capital represents such a second-based change, as we shall see below.

- $\quad$ The third-order changes are transformations of the overall goals of the policy, changes in the cognitive and normative framework of the networking regulatory regime on which it is based, accompanied by first and 
second-order changes. These changes might lead to deep-rooted and longterm public innovations, for example, moves that remain path-dependent and also aspire to reinvent the state and to rediscover institutions in new settings but.

We shall see below that the traditional Scandinavian model of the welfare state has undergone such a move, and, as a result, has become known as the contemporary Nordic model. This model has combined universal social security and active labour-market policies innovatively, and this combination constitutes a deep-rooted and long-term, path-dependent social capital. This social capital may be objectively experienced by individuals and collectives and is suitable for studies that employ empirical, statistical measurements. Third-order social capital represents substantial public innovation.

\section{Social capital of the Nordic type.}

In a transnational perspective, we may view social capital in the Nordic countries as a transformation of the traditional Scandinavian welfarestate capacity to what now is named the contemporary social capital of the Nordic model (Veggeland 2007).

The aforementioned term of 'Nordic flexicurity policy' represents contextually collective action and a long-term social capital embracing both economic and social aspects. The driving force is a path-dependent political will to sustain a national partnership between the regulatory authorities, the unions of employees and the employers, and the people. The goal is good governance in the forms of universal social security, institutional stability, and economic and competitive advantages. Universal social security lays the foundation for the development of flexible labour markets that all the partners benefit from in different ways, including benefits irreducible to economic factors.

The Nordic Active Labour Market Policy (ALMP) is another expensive public and private contribution to the social capital of the grand partnership and the flexicurity concept. ALMP is an important part of the state authorities' responsibility for planning, building, restoring, and protecting human capital, and for making human resources the basic element of partnerships and social-capital building. ALMPs compel by regulatory innovations a range of public means and measures in order to function together, and the execution of these means and measures must take place within the framework of the universal welfare-state model. The mechanisms behind the Nordic flexicurity are as follows:

- $\quad$ Universal welfare and social security allow employees to feel free to move and change job and partners - safety and equal access to welfare rule independently of geography, position, employer, and network attachment. 
- $\quad$ ALMP performs collaborative governance by complex public-private partnership policies (social capital) and by education, individual training, and life-long learning (human capital). The performance involves not only the public sector but also partners across all sectors - from public services to private actors to NGOs.

- $\quad$ Nordic flexicurity is a nationally implemented policy concept but is basic for partnership-building and domestic regional development capacities and across borders. Flexicurity reproduces long-term partnership arrangements, an effective labour market, high labour productivity, high employment rate, and a high level of social and human capital.

All together Nordic flexicurity as an important part of the social capital concept is indeed expensive and imposes a high tax burden on the citizens, but even so the policy sustains its legitimacy out of its double efficiency with regard to returning economic revenues and social security. Comparative figures suggestive of the OECD data were made available in the 2004 World Economic Forum report on the Lisbon Agenda. In a European perspective, these figures reveal that if the Anglo-Saxon USA were, for comparative purposes, an EU member state, it would rank fourth behind three existing member states on an overall assessment of economic competitiveness. Remarkably, the top countries - Denmark, Sweden, Finland and Norway - were all Nordic states.

The consistent performance of the Nordic social capital is striking across a range of indicators (Veggeland ed. 2016):

- $\quad$ Economic growth;

- $\quad$ Labour productivity;

- $\quad$ Active Labour Market Policy (ALMP);

- $\quad$ Labour-market flexibility but social security, called 'flexicurity';

- $\quad$ Regional and local development policy;

- $\quad$ Research and development investment;

- $\quad$ Performance in the high-tech and telecom sectors;

- $\quad$ Rates of employment (including among women and older workers).

In this context, social capital as flexicurity turns out to be not only 'capital' but also 'social'. Szreter and Woolcock (2004) were indeed right in their statement about Sweden; countries in the region '(provide) greater social capital to its citizens than do other countries'.

\section{The threat of non-maintenance}

Basically, social-capital building may promote good governance and long-term positive consequences in one polity context, but in another context it may turn out very differently. From the analysis of this paper, we learn that 
social models and administrative tradition do influence the quality and practical outcome of partnership formations.

Professor Vicente Navarro of Johns Hopkins University asks (2004: 2) in a critical commentary: 'Is capital the solution or the problem'? In a response to Theodore Lowi's statement, his answer is that dominant neoliberal discourse in social science as a consequence of the 1980s, we have seen the appearance of concepts such as social capital and human capital. He writes:

'This dominance by an economic discourse was herald as an indicator of the supposed triumph of capitalism - which had closed any debate about the type of society and economic system we might want and refocused the debate on how to manage the only system we have. Consequently, the purpose of all social actions is reduced to accumulation of capital so that the individual can compete better. The capital might be physical, monetary, human, or social, but it is capital nevertheless'.

Thus, as 'social capital' has become an economic term in the era of neo-liberalism, it seems that flexicurity likewise is being threatened by the same shift of connotation away from a policy for national collective action. In the political debate, even in the Nordic countries, the economic connotation is given superiority as a policy for increasing European and national competitiveness and economic growth rather than for keeping the policy as a steady path to good welfare policy in the global age. The flexicurity policy faces serious challenges today by the embracing of labour immigration from Europe and other, more remote regions. The focus tends to change from the social connotation to the economic. The Nordic model is in drift; the maintenance of path-dependence is threatened (Taylor-Gooby (ed.) 2004, Veggeland 2004, 2007, Tranøy 2006, Timonen 2004, Olsen 2005).

\section{Short conclusion}

Flexicurity policy as social-capital building should remain a path for collective action and for solidarity, for reasons of democracy, social security and welfare, and for keeping the labour market flexible. As academics, we are not really responsible for policy performance, but we do have another responsibility. We are responsible for the definition of the terms and thereby the language in use. With reference to Navarro's statement above, there is a need in social science today to break the trend that supports the dominance of economic language and the considerable reductionism and myopia this dominance generates. 


\section{References:}

1. Amin, Ash and Thrift, Nigel (1995a), 'Globalization, institutional 'thickness' and local economy'. Healey, Patsy et. al. (eds.), Managing Cities, Chiester: John Wiley.

2. Beetham, David, Byrne, Lain, Ngan, Pauline and Weir, Stuart (2002), Democracy under Blair. A Democratic Audit of the United Kingdom, London: Politico's Publishing.

3. Black, Julia (2005), '’What is regulatory innovation'? Black, Julia, Lodge Martin, Thatcher, Mark (eds.) (2005), Regulatory Innovation. A Comparative Analysis, Cheltenham, UK - Northampton, MA, USA: Edward Elgar.

4. Cassese, Sabino (2003), 'The Age of Administrative Reform', in Hayward, Jack and Menon, Anand (eds.) (2003), Governing Europe, Oxford: Oxford University Press, pp. 128-138.

5. Cini, Michelle (2004), 'Intergovernmentalism', Cini, Michelle (ed.) (2004), European Union Politics, Oxford: Oxford University Press.

6. Hayward, Jack and Menon, Anand (eds.) (2003), Governing Europe, Oxford: Oxford University Press.

7. Higdem, Ulla (2007), Regional Partnerships and their Constructions and Implementations. A case study of the counties of Oppland, Hedmark, and Østfold', Dr. scientarium thesis, Norwegian University of Life Sciences.

8. Iversen, Torben (2005), Capitalism. Democracy and Welfare, Cambridge: Cambridge University Press.

9. Keating, Michael (1998), The New Regionalism. Territorial Restructuring and Political Change, Cheltenham (UK) and Lyme US: Edward Elgar.

10. Knill, Christoph (2001), The Europeanization of the National Administrations, Cambridge: Cambridge University Press.

11. Kuhnle, Stein (2000), 'The Scandinavian Welfare State in the 1999s: Challenged but Viable', Ferrera, Maurizio and Rhodes, Martin (eds), Recasting European Welfare States, London: Frank Cass, pp. 209228.

12. March, James and Olsen, Johan P. (1989), Rediscovering Institutions: The Organizational Basis of Politics, New York: Free Press.

13. Meyer, J. W. (2000), 'Globalization: sources and effects on national states an societies', International Sociology, 15 (2), 233-48.

14. Moran, M. (2003), The British Regulatory State: High Modernism and Hyper-Innovation, Oxford: Oxford University Press.

15. Navarro, Vincent (2002), 'A critique of social capital', International Journal of Health Service 2002: 32:424-32. 
16. Navarro, Vincent (2004), 'Commentary: Is capital the solution or the problem'? International Journal of Epidemiology 2004: 33: 1-3.

17. Olsen, J. P. (2005): Maybe it is time to rediscover bureaucracy? Working Paper 10. Arena University of Oslo.

18. Osborne, D. and Gaebler, T. (1993), Reinventing Government, New York: Plume.

19. Pedersen, T. H. (2008), Fra kommunale forvaltninger til forvaltningsløse kommuner. En translasjonsstudie av reformgrepet utflatning $i$ danske og norske kommuner, PhD-thesis. Tromsø: Tromsø University.

20. Pierson, Paul (2004), Politics in Time. History, institutions and social analysis, Princeton and Oxford: Oxford University Press.

21. Porter, Michael (2000), Clusters and the new economics of competitions', Harvard Business Review: Vol 76, 77-90.

22. Putnam, Robert D. (1993), Making Democracy Work. Civic Traditions in Modern Italy, Princeton: Princeton University Press.

23. Putnam, Robert D. (ed.) (2002), Democracies in flux: the evolution of social capital, Oxford: Oxford University Press.

24. Røvik, K. A. (2007), Translasjoner og Trender. Ideer som former det 21. århundrets organisasjon (Translations and Trends. Ideas that shape the 21. century), Bergen: Fagbokforlaget.

25. Scharpf, Fritz (1999), Governing in Europe. Effective and democratic?, Oxford: Oxford University Press.

26. Sørensen, Aa B and S. Spillerman (eds.) (1993), Social theory and social policy: essays in honour of James S. Coleman, London: Praeger.

27. Szreter, S. and Woolcock, M. (2004), 'Health by association? Social capital, social theoty and political economy of public health', International Journal of Epidemiology 2004: 33: DOI: 10, 1093/ije/dyh013.

28. Taylor-Gooby, Peter (ed.) (2004), New Risks, New Welfare. The Transformation of European Welfare State, Oxford: Oxford University Press.

29. Timonen, Virpi (2004), 'New Risks - Are They Still New for the Nordic Welfare States'? Taylor-Gooby, Peter (ed.) (2004), New Risks, New Welfare. The Transformation of European Welfare State, Oxford: Oxford University Press, pp. 55-83.

30. Tranøy, Bernt Sofus (2006), Markedets makt over sinnene (The power of the market over the souls) Oslo, Aschehoug.

31. Veggeland, Noralv (2004), The Competitive Society. How democratic and effective?, Kristiansand: Norwegian Academic Press. 
32. Veggeland, Noralv (2007), Paths of Public Innovation in the Global Age. Lessons from Scandinavia, Cheltenham, UK - Northampton, MA, USA: Edward Elgar.

33. Veggeland, Noralv (2013), Essays on Regulatory Governance, New York: Nova Science Publishers.

34. Veggeland, Noralv (ed. 2016), The Current Nordic Welfare State Model, New York: Nova Science Publishers.

35. Warden, F. van (1995), 'National Regulatory Styles. A Conceptual Scheme and the Institutional Foundations of Styles', in Unger, B. and Warden, van F. (eds), Convergence or Diversity? Internationalization and Economic Policy Response, Aldershot, UK and Brookfield, US: Edward Elgar Publishing, pp. 45-97. 